\title{
Estimation of clonal contribution to cone and seed crops in a Sitka spruce seed orchard *
}

\author{
K Chaisurisri 1,**, YA El-Kassaby 1,2,*** \\ ${ }^{1}$ Faculty of Forestry, University of British Columbia, Vancouver, BC, V6T 1Z4; \\ 2 Pacific Forest Products Ltd, Saanich Forestry Centre, 8067 East Saanich Rd, \\ $R R \# 1$, Saanichton, BC, VOS 1 MO Canada
}

(Received 17 November 1992; accepted 12 May 1993)

\begin{abstract}
Summary - The relationship between reproductive energy and reproductive success and its impact on parental balance were studied in a clonal Sitka spruce (Picea sitchensis (Bong) Carr) seed orchard over 2 crop-years. Parental reproductive output and effective female population number estimates gave a good indication of the parental imbalance in the orchard crops, however, they did not show the existing differences in reproductive energy and reproductive success among the studied clones. Parental balance estimates based on seed data were more accurate than those based on cone counts. The orchard's parental balance showed consistent improvement over time. Two management options, namely, supplemental-mass-pollination and harvesting the cone crop by subsets of cone production level, were proposed to alleviate parental imbalance.
\end{abstract}

Sitka spruce / seed orchard / parental balance / effective population number / reproductive energy / reproductive success

Résumé - Estimation de la contribution clonale à la production de cones et de graines dans un verger à graines d'épicéa de Sitka. Cet article étudie les relations entre énergie reproductive (nombre de cones produits par un arbre) et succès reproductif (nombre de graines produites). L'impact de ces 2 facteurs sur la contribution de chaque clone à la production de graines d'un verger d'épicéa de Sitka durant 2 années successives est également abordé. Les estimations du nombre efficace d'arbres mères rendent bien compte de la contribution très inégale des différents clones à la production de graines. Cependant, elles ne mettent pas en évidence les différences clonales entre énergie reproductive et succès reproductif. La contribution relative de chaque parent basée sur la production de graines est plus précise que celle basée sur la production de cones. L'amplitude de variation de ces contributions clonales tend à diminuer avec l'âge du verger. Une alternative à la

* The manuscript represents a portion of the senior author's Ph D dissertation.

** Permanent address: ASEAN-Canada Forest Tree Seed Centre, Muck-Lek, Saraburi 18180 Thailand.

*** Correspondence and reprints 
contribution très inégale est proposée : pollinisation complémentaire artificielle et récolte individualisée des cones par classe de production.

épicéa de Sitka / verger à graines / contribution parentale / taille efficace de population / énergie reproductive / succès reproductif

\section{INTRODUCTION}

A seed orchard is a plantation of genetically superior individuals managed to promote their intermating while preventing pollen contamination (Zobel et al, 1958). The genetic value and diversity of orchardproduced seeds are expected to be high throughout successive generations. Several biological conditions are required for seed orchards to meet these objectives. These are: 1) parental balance (ie, equality of male and female gametes among the orchard clones); 2) reproductive phenology synchrony; 3) random mating; 4) no incompatibility and selection between fertilization and germination; and 5) minimal or no pollen contamination (Eriksson et al, 1973). However, it is commonly observed that seed orchards often deviate from their "ideal" expectations (see El-Kassaby, 1989, for review). For example, differences in reproductive output have been reported for several species (Eriksson et al, 1973; Jonsson et al, 1976; O'Reilly et al, 1982; Schmidtling, 1983; Griffin, 1982; Bryam et al, 1986; Schoen et al, 1986; Askew, 1988; El-Kassaby et al, 1989; El-Kassaby and Reynolds, 1990; Boes et al, 1991; Roberds et al, 1991). Thus, the genetic representation of the orchard's clones varies in the seed crop.

Parental balance of seed orchard's crops is commonly summarized by coneyield curves (Griffin, 1982). In this method the seed orchard's clones are ranked from high to low yield and cumulative percentage calculations are plotted against the percentage of clones counted. With this presentation the percent contribution of any proportion of clones to the cone crop can easily be estimated. The concept of effective population number also can be used to demonstrate the deviation from the idealized case (ie, equal contribution; Falconer, 1986). The effective number of a natural population is always expected to be less than the number of adults of reproducing age for one or more reasons: 1) unequal numbers of males and females; 2) temporal variation in population number; and 3) greater than binomial or Poisson variability in the number of progeny per plant (Crow and Kimura, 1970; Crow and Denniston, 1988).

The use of cumulative yield curves or effective population number based on seed-cone count assumes that reproductive energy (ie, number of seed-cones) is equal to reproductive success (ie, number of filled seeds per cone). Reynolds and El-Kassaby (1990) used cumulative seedcrop data to assess parental balance in a Douglas fir seed orchard, and found the cumulative seed-yield curve is a better parameter than cone-yield in assessing parental balance with respect to (in terms of) genetic diversity and family representation.

This study was conducted to: 1) contrast methods of evaluating parental balance and female effective population number; 2) determine parental imbalance in this orchard; and 3) contrast parental imbalance over years.

\section{MATERIALS AND METHODS}

The study was conducted in the Pacific Forest Products Ltd Sitka spruce seed orchard. The or- 
chard is locoated in Saanichton, British Columbia (latitude $48^{\circ} 35^{\prime} \mathrm{N}$, longitude $123^{\circ} 24^{\prime} \mathrm{W}$ ) and consists of 139 clones (averaging 9.3 ramets per clone) selected from elevations between 0 and $415 \mathrm{~m}$ on western Vancouver Island, Washington and Oregon. The orchard was established in 1971 in a random single-tree mix over 3 unequal blocks. Trees are spaced $3 \mathrm{~m}$ apart and kept at approximately $4 \mathrm{~m}$ in height by toppruning. The seed orchard is $10 \mathrm{~km}$ away from the nearest Sitka spruce stand, so Sitka spruce background pollen is considered to be negligible.

During 1988 and 1990 harvests, the cone crop of every clone in the seed orchard was counted to determine the parental balance for these $2 \mathrm{yr}$. In this study, cones were collected from 96 ramets of 22 clones (1988 crop) and 142 ramets of 18 clones (1990 crop). The sampled (ie, studied) clones were randomly selected from the seed orchard. Where possible, a sample of 5 cones was randomly taken from each ramet for seed extraction. Cone samples were air dried, and seeds were extracted, dewinged and cleaned by hand. Numbers of filled and empty seeds (identified by $\mathrm{X}$-ray) were recorded.

Total seed yields were assessed for the 1990 crop. Individual clone's average seed weight was determined using weight data from 100 individual seeds per ramet within every clone, then the total seed crop count was calculated by dividing bulk seed weight of each ramet within every clone by the corresponding average individual seed weight. In addition, germination tests were conducted to provide viable seed production data. Germination test description was reported elsewhere (Chaisurisri et al, 1992).

One-way ANOVA was used to analyze the seed and cone counts of 1988 and 1990 crops. Due to a close relationship among total seeds $(r=0.81, P<0.01)$, filled seeds $(r=1.00, P<$ 0.01 ), and viable seed data, filled seed data only were used in the analysis. The relationship between clonal cone and seed crops was assessed by Pearson's product-moment correlation.

Data on cone, total seeds, filled seeds, and viable seed productions were used to estimate the female effective population number $\left(N_{e f}\right)$ (Crow and Kimura, 1970, p 324):

$$
N_{e f}=\frac{1}{\Sigma x_{i}^{2}}
$$

where $N_{e f}=$ female effective population number; $x_{i}=$ proportion of ith clone contribution to the orchard's crop.

\section{RESULTS AND DISCUSSION}

The randomly selected clones for 1988 and 1990 were representative samples of the production range in the seed orchard (fig 1), indicating that the sampled clones will provide an unbiased estimate of cone and seed yield for the whole orchard. The relationships between seed-cone and filled-seed production was positive and significant for both $1988(r=0.86, n=22, P<$ $0.01)$ and $1990(r=0.81, n=18, P<0.01)$ crops. The coefficients of determination were high for $1988\left(r^{2}=0.75\right)$ and 1990 $\left(r^{2}=0.66\right)$ crops, indicating that the relationship between cone and seed accounts for a large proportion of variation in the data. Clonal differences accounted for 34$41 \%$ of total variation in cone and seed crops over the 2 crop-years (table I). Thus, broad-sense heritability for reproductive traits in this study ranged from 0.34 to 0.41 indicating moderate genetic control. The remaining variation $(59-66 \%)$ resided within-clone (ie, among ramets within clones). A change in yield rank between cone and seed indicated that reproductive energy and reproductive success differed among clones for both 1988 and 1990 crops (figs 2 and 3). The 1988 crop showed that 6 out of 22 studied clones (ie, 27\%) (No's 36, $124,53,27,71$ and 184) maintained the same rank as cone and seed producers while only 4 out of 18 clones (ie, 22\%) (No's 421, 20, 411 and 416) of 1990 crop kept the same rank (figs 2 and 3). Comparing the performance of the 4 commonly 
Table I. Estimates of the percentages of variance components for cone and seed production among Sitka spruce clones for 1989 and 1990 crops.

\begin{tabular}{|c|c|c|c|c|c|c|c|}
\hline \multirow{2}{*}{$\begin{array}{l}\text { Source } \\
\text { of variation }\end{array}$} & \multirow{2}{*}{$\begin{array}{c}\text { Expected } \\
\text { Mean squares a }\end{array}$} & \multicolumn{3}{|c|}{$1988 \mathrm{crop}$} & \multicolumn{3}{|c|}{1990 crop } \\
\hline & & $d f$ & Cone & Seed & $d f$ & Cone & Seed \\
\hline Among clones & $\sigma_{e}^{2}+K \sigma_{c}^{2}$ & 21 & $37.073^{* *}$ & $38.445^{\star *}$ & 17 & $33.548^{* *}$ & $41.014^{* *}$ \\
\hline Within clones & $\sigma_{e}^{2}$ & 76 & 62.927 & 61.555 & 124 & 66.452 & 58.986 \\
\hline
\end{tabular}

* Significant at $P<0.01$. a $\sigma_{\mathrm{e}}^{2}=$ variance due to differences among ramets within the same clone; $\sigma_{\mathrm{c}}^{2}=$ variance due to differences among clones; $K=$ coefficient of variance component.

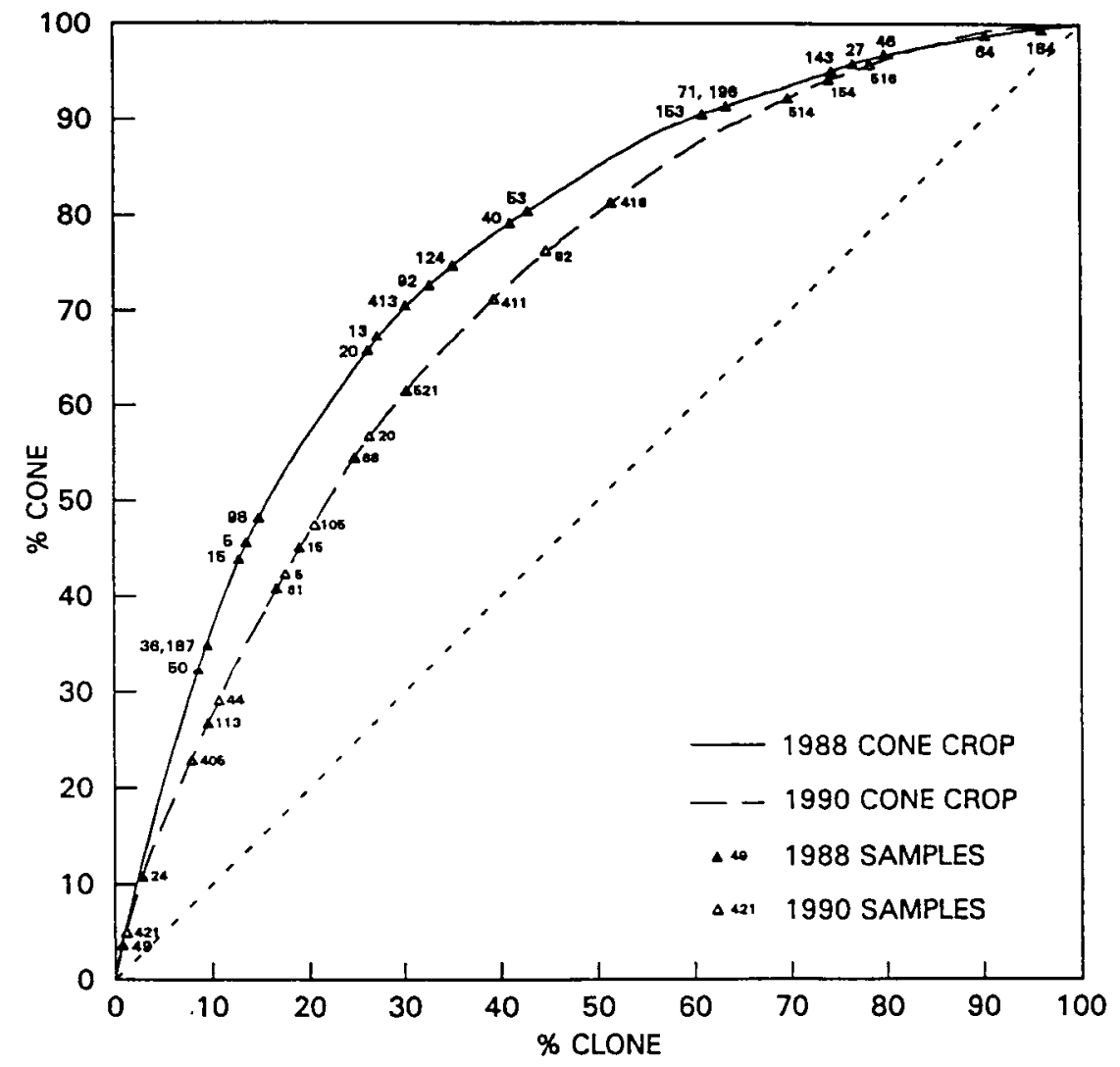

Fig 1. Cone crop parental balance curve based on the entire orchard clones ( $N=139$ ), indicating contributions of $1988(n=22)$ and $1990(n=18)$ sampled clones. 


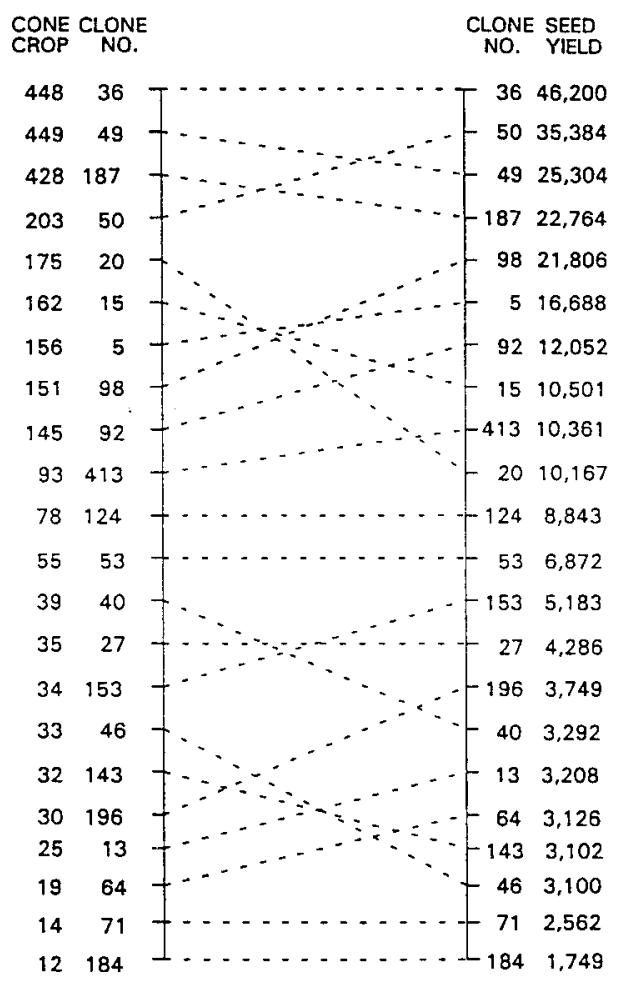

Fig 2. Rank order for 22 Sitka-spruce clones, 1988 crop, based on cone and seed yields.

studied clones over the 2 crop-years showed that: 1) 2 clones have maintained their differential reproductive energy and output performance (No's 15, 92); and 2) 2 clones changed from being less efficient in 1988 to more efficient or maintained the same rank in 1990 (No's 5 and 20, respectively).

The proportions of female effective and actual numbers $\left(N_{e f} / N\right)$ were 0.45 and 0.50 for seed-cone and filled-seed crops, respectively, for 1988. For the 1990 crop, these proportions were $0.70,0.61,0.59$ and 0.58 for cone, total seed, filled seed and viable seed productions, respectively.
The deviation of the effective population number from an ideal population indicates the presence of disproportional contribution by the studied clones. It is noteworthy that this ratio showed consistent decline over yield estimation procedures and that the results obtained from seeds is more accurate than that from cones. In addition, the results obtained for 1990 were better than those from 1988, indicating improvement over time.

The parental balance records for this seed orchard in 1985, 1986 and 1987 were "20:80" (ie, $20 \%$ of the orchard's clones produced $80 \%$ of the total cone crop), "35:80" and "42:80", respectively (ElKassaby and Reynolds, 1990). In this study, the cone crop parental balances for 1988 and 1990 were "42:80" and "48:80", respectively, indicating improvement with age. Similar improvement over time has

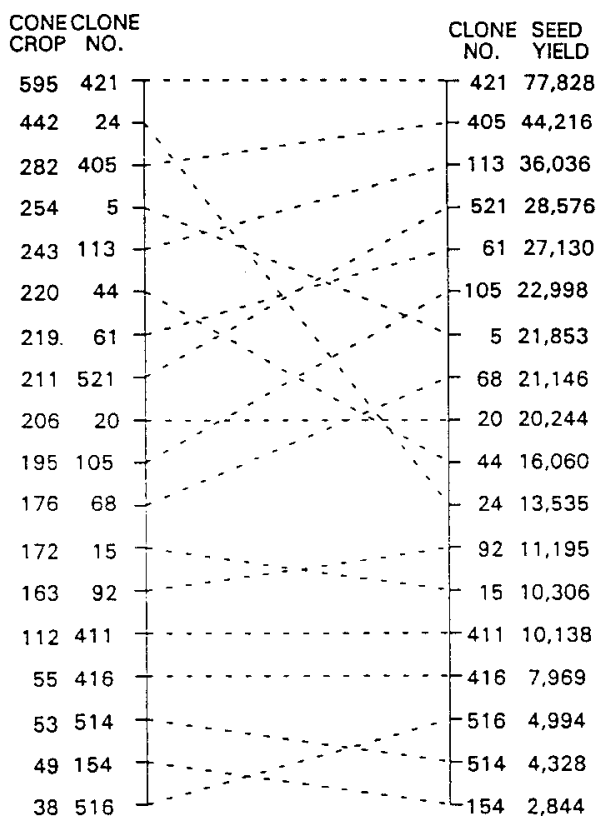

Fig 3. Rank order for 18 Sitka-spruce clones, 1990 crop, based on cone and seed yields. 
been observed also for loblolly pine (Byram et al, 1986), and Douglas fir (ElKassaby et al, 1989).

The results obtained from the coneyield curves and the female effective number provided an indication of the degree of deviation from the ideal equal contribution; however, these parameters did not provide an insight into the relationship between reproductive energy and reproductive success as shown in figures 2 and 3 . It is known that fecundity is under genetic control (Jonsson et al, 1976; El-Kassaby, 1989), therefore, certain clones may consistently produce high or low seed crops due to their genetic predisposition.

Supplemental-mass-pollination (SMP) has been proven to be a vital tool for improving reproductive success for Sitka spruce due to the reproductive phenology displacement between male and female strobili (El-Kassaby and Reynolds, 1990). SMP, therefore, could improve parental contribution as well as reproductive success. If SMP is used as a management option for adjusting parental imbalance, then the proportion of pollen in the pollen mixes should emphasize those clones with low seed-cone or seed production, thus their gametes are over emphasized in the seed crop through their male part.

Harvesting the cone crop into subsets that consist of high, intermediate, and poor seed-cone producers may improve the parental balance within each subset to a level that might be better than harvesting the entire crop as 1 lot. For example, the 1988 parental balance for the entire orchard was "42:80". When this crop was divided into 3 subsets, parental balances observed were " $54: 80$ ", "67:80" and "71:80" for poor, good and intermediate cone producers, respectively (fig 4). The proportions of female effective to actual population numbers were $0.41,0.74,0.87$ and 0.93 for the entire crop and poor, high and intermediate cone producers, respectively, indicating improvement of the parental balance due to grouping clones into cone production levels. This approach will produce 3 evenly balanced seedlots from that seed orchard. The use of these 3 seedlots in seedling production will provide a change to produce genetically balance seedling crops.

In conclusion, the present study has demonstrated the following: 1) clonal differences in reproductive energy and reproductive success exist in Sitka spruce; 2) reproductive traits are under moderate genetic control; 3) the determination of parental contribution to seed crop should be conducted on a yearly basis; 4) parental balance has improved with age; and 5) SMP and/or harvesting the cone-crop by subsets of cone production level are possible options for improving clonal representation in seed crops.

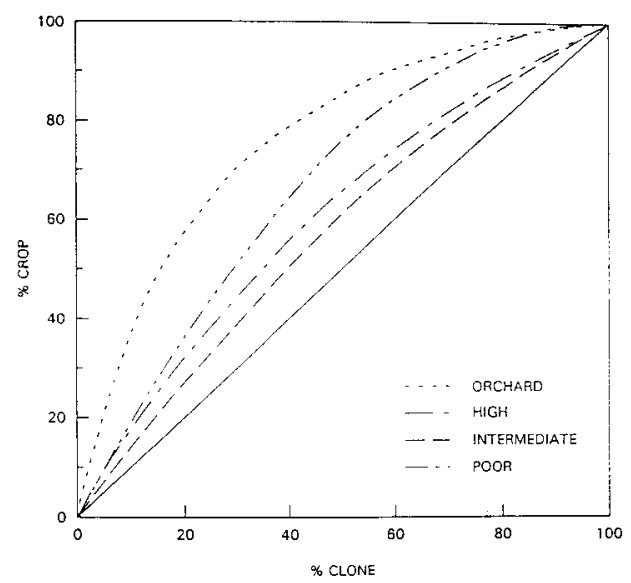

Fig 4. 1988 parental balance based on the entire orchard crop and 3 subsets of high, intermediate and poor cone producers. The straight line represents equal contribution. 


\section{ACKNOWLEDGMENTS}

The authors thank MD Meagher, DGW Edwards and SA Barnes for reviewing the manuscript and KP Brady for technical assistance. This study is supported in part by ASEAN-Canada Forest Tree Seed Centre (CIDA) grant to KC and Pacific Forest Products Ltd.

\section{REFERENCES}

Askew GR (1988) Estimation of gamete pool compositions in clonal seed orchards. Silvae Genet 37, 227-232

Boes TK, Brandle JR, Lovett WR (1991) Characterization of flowering phenology and seed yield in a Pinus sylvestris clonal seed orchard in Nebraska. Can For Res 21, 1721-1729

Bryam TD, Lowe WJ, McGriff JA (1986) Cloncal and annual variation in cone production in loblolly pine seed orchards. For Sci 32, 10671073

Chaisurisri K, El-Kassaby YA, Edwards DGW (1992) Genetic control of seed size and germination in Sitka spruce. Silvae Genet 41, 348-355

Crow JF, Denniston C (1988) Inbreeding and variance effective population numbers. EvoIution 42 (3), 482-495

Crow JF, Kimura M (1970) An Introduction to Population Genetic Theory. Happer \& Row Publ, NY, $591 \mathrm{p}$

El-Kassaby YA (1989) Genetics of Douglas-fir seed orchards: expectations and realities. In: Proc 20th Southern Forest Tree Improvement Conference, 87-109. Charleston, SC

El-Kassaby YA, Fashler AMK, Crown M (1989) Variation in fruitfulness in a douglas-fir seed orchard and its effect on crop management decisions. Silvae Genet 38, 113-121

El-Kassaby YA, Reynolds S (1990) Reproductive phenology, parental balance, and supplemental mass pollination in a Sitka-spruce seed orchard. For Ecol Manage 31, 45-54

Eriksson G, Jonsson A, Lindgren D (1973) Flowering in a clone trial of Picea abies Karst. Stud For Suec 110, 1-45

Falconer DS (1986) Introduction to Quantitative Genetics. Longman Sci \& Tech, NY, 2nd ed

Griffin AR (1982) Clonal variation in radiata pine seed orchards: I. Some flowering, cone and seed production traits. Aust $J$ For Res 12, 295-302

Jonsson A, Ekberg I, Eriksson G (1976) Flowering in a seed orchard of Pinus sylvestris $\mathrm{L}$. Stud For Suec 135, 1-38

O'Reilly C, Parker WH, Barker JE (1982) Effect of pollination period and strobili number on random mating in a clonal seed orchard of $\mathrm{Pi}$ cea mariana. Silvae Genet 31, 90-94

Reynolds S, EI-Kassaby YA (1990) Parental balance in Douglas-fir seed orchard cone crop vs seed crop. Silvae Genet 39, 40-42

Roberds JH, Friedman ST, El-Kassaby YA (1991) Effective number of pollen parents in clonal seed orchards. Theor Appl Genet 82, 313-320

Schmidtling RC (1983) Genetic variation in fruitfulness in a loblolly pine seed orchard. Silvae Genet 32, 76-80

Schoen DJ, Denti D, Stewart SC (1986) Strobilus production in a clonal white spruce seed orchard: evidence for unbalanced mating. Silvae Genet 35, 201-205

Zobel BJ, Barber J, Brown CL, Perry TO (1958) Seed orchards. Their concept and management. J For 56, 815-825 